\title{
Regional Multilateralism: \\ The Right to Protect, not the Responsibility to Protect, in Africa
}

\author{
Obinna Franklin Ifediora \\ obinna.ifediora@uq.edu.au \\ The University of Queensland
}

\begin{abstract}
The African Union (AU) has rejected R2P and opposed the UN Security Council-authorized military action in Libya for human rights protection, claiming primacy in decision-making on peace and security interventions on the continent. Yet, existing studies have assumed that the right to protect, as the AU established in article 4(h) of the Constitutive Act, is compatible with R2P. Drawing on the concept of regional multilateralism, this article argues that the right to protect involves a unique African logic and ambition, albeit with an extraordinary significance for global security governance. Particularly, the right to protect is a robust, bold, stable, and uncontested international security regime, which favourable Permanent Five members of the Security Council can turn to when facing the twin problems of legitimacy and veto-induced paralysis. However, such P5 members must embrace the AU's novel principle: continental sovereignty, which underlines the AU's primacy claims in decision-making in peace and security.
\end{abstract}




\section{Introduction}

The African Union (AU) has often resisted the UN Security Council's military and nonmilitary actions to enforce $\mathrm{R} 2 \mathrm{P}$ and protect human rights, claiming primacy in decision-making on peace and security interventions on the continent. In Libya, the AU opposed the Security Council-authorized NATO's use of force, stressing diplomacy and mediation. ${ }^{1}$ Likewise, the AU opposed the Security Council-mandated ICC investigation of the genocidal war in Sudan, describing the pursuit of justice as a threat to peace, security, and stability. ${ }^{2}$ The AU primacy claim is a challenge to the UN Security Council's global authority and primary responsibility for the maintenance of international peace and security.

Existing studies $^{3}$ have assumed that R2P is compatible with the AU's 'right to intervene' for human protection or what this article describes as the right to protect ${ }^{4}$ under article 4(h) of the Constitutive Act of the AU. These studies have essentially subsumed the right to protect under $\mathrm{R} 2 \mathrm{P}$. The apparent reasoning is that since $\mathrm{R} 2 \mathrm{P}$ and the right to protect share the same objectives, then it makes sense to place the regional principle under the global

\footnotetext{
${ }^{1}$ African Union, Assembly Decision, Assembly/AU/Dec. 385 (XVII), 30 June - 1 July 2011, paras. $3,7$.

${ }^{2}$ African Union, Common African position on the UN review of peace operations, PSC/PR/2(DII), 29 April 2015, paras. 5-6.

${ }^{3}$ Tim Murithi, 'The responsibility to protect, as enshrined in article 4 of the Constitutive Act of the African Union,' African Security Studies 16:3, 2007, pp. 14-24; Atuobi, Samuel, and Kwesi Aning, 'Responsibility to protect in Africa: An analysis of the African Union's peace and security architecture,' Global Responsibility to Protect, 1:1, 2009, pp. 90-113; Paul D. Williams, 'The 'responsibility to protect': Norm localisation, and African international society,' Global Responsibility to Protect 1:3, 2009, pp. 392-416; Dan Kuwali, and Frans Viljoen, eds., Africa and the responsibility to protect: Article $4(h)$ of the African Union Constitutive Act (London: Routledge, 2013); Sarkin, Jeremy, ' The responsibility to protect and humanitarian intervention in Africa,' Global Responsibility to Protect 2:4, 2010, pp. 371-87; Mwanasali, Musifiky, 2010, 'The African Union, the United Nations, and the responsibility to protect: Towards an African intervention doctrine,' Global Responsibility to Protect 2:4, pp. 388-413; Kuwali, Dan, The responsibility to protect: Implementation of article 4(h) intervention (Leiden; Boston: Martinus Nijhoff, 2011); Kwesi Aning, and Fiifi Edu-Afful, 'African agency in R2P: Interventions by African Union and ECOWAS in Mali, Cote d'Ivoire, and Libya,' International Studies Review 18:1, 2016, pp. 120-133; Sarkin, Jeremy, 'Is the African Union's position on non-indifference making a difference? The implementation of the responsibility to protect (R2P) in Africa in theory and practice,' Journal of African Union Studies 5:1, 2016, pp. 5-37; Adigbuo, Ebere R., 'The African Union, R2P and the challenges of capability,' Journal of African Union Studies 8:1, 2019, pp. 115-33.

${ }^{4}$ I choose the term, right to protect, to reflect more accurately the logic, the legislative intent and African leaders' aim for adopting the unprecedent legal provision, which is that the Assembly has the permission of the entire continent, including the leaders and people, to undertake all necessary actions to safeguard African populations from genocide, war crimes, and crimes against humanity.
} 
principle consistent with the concept of global multilateralism ${ }^{5}$ in international security governance through the Security Council, which underscores the dominance of universal institutions. However, AU's primacy claim and opposition to the Security Council's military and nonmilitary measures problematize current presumptions of compatibility and multilateralism and raise the research question: what explains AU's resistance to the Security Council's robust and non-robust measures and primacy claim in peace and security?

This article argues the explanation of AU primacy claims and opposition to robust interventions entails understanding the rationale for creating the right to protect, which involves interpreting regional and global multilateral efforts to reconcile state sovereignty with military intervention for human rights protection. Although the right to protect and the R2P norms share a similar history and broader goals of preventing genocide, war crimes, and crimes against humanity, the right to protect principle followed different logic and ambition, which falls into three broad elements: 1) African leaders were more interested in establishing an unassailable legal foundation for the use of force to protect human rights; 2) African leaders were motivated to create a robust, incontestable norm on military intervention in 'grave circumstances' like genocide, war crimes, and crimes against humanity; and 3) more importantly, African leaders intended to claim primacy in decision-making on peace and security, particularly the use of force. In other words, the right to protect is concerned with the legitimacy of the use of military force, which the AU has defined as the primacy of African norms and institutions. The implication is that the $\mathrm{AU}$, in conjunction with external powers, must authorize the use of force for human rights protection under article 4(h). Consequently, the AU has rejected $\mathrm{R}^{2} \mathrm{P}^{6}$ and questioned the legality and the legitimacy of the UN Security Council to authorise military

\footnotetext{
${ }^{5}$ Thakur, Ramesh, and Luk van Langenhove, 'Enhancing global governance through regional integration,' Global Governance: A Review of Multilateralism and International Organizations 12:3, 2006, pp. 233-240.

${ }^{6}$ African Union, The common African position on the proposed reform of the United Nations: "The Ezulwini Consensus," Ext/EX.CL/2 (VII), 7-8 March 2005, p. 6. The Assembly has consistently endorsed the Ezulwini Consensus since 2006, including recently, see African Union, Assembly Decision, Assembly/AU/Dec.766 (XXXIII), 09-10 February 2020, para. 7.
} 
interventions for human rights protection under Chapter VII of the UN Charter, specifically for implementing R2P, such as in Libya. ${ }^{7}$

The significance of this article is to underscore that the right to protect is a unique and ambitious global security norm. By untying article 4(h) from R2P, this paper establishes that the right to protect is a more robust, bolder, stable, and uncontested security norm available to the Security Council when facing the twin problems of veto-induced paralysis and legitimacy. First, if one of the Permanent Five (P5) members of the Security Council vetoes a Chapter VII resolution, then favourable members must consider alternative norms, and the right to protect is an option, not an appendage to R2P that becomes useless because of the lack of consensus. Second, given the lack of inclusion in the P5, the AU questions the legitimacy of the Security Council, so the right to protect can legitimize the Council's actions. The implication is that the Security Council must recognize the AU novel norm: continental sovereignty, ${ }^{8}$ which underpins AU primacy claim over decision-making. Continental sovereignty means that the AU has precedence in decision-making on peace and security. Thus, the Security Council needs to engage in strategy dialogues with the AU on the potential use of the right to protect in future interventions in Africa and globally.

This article adopts a two-pronged method of analysis. First, it implements the concept of regional multilateralism ${ }^{9}$ to interpret the development of the right to protect norm and draw a distinction with global multilateralism and the emergence of $\mathrm{R} 2 \mathrm{P}$, underscoring that the right

\footnotetext{
${ }^{7}$ For some insightful thoughts on the vital question of legitimacy, see Ralph, Jason, and Adrian Gallagher, 'Legitimacy faultlines in international society: The responsibility to protect and prosecute after Libya,' Review of International Studies 41:3, 2015, pp. 553-573; Adebajo, Adekeye, 'The revolt against the West: Intervention and sovereignty,' Third World Quarterly 37:7, 2016, pp. 1187-1202; Kurtz, Gerrit, and Philipp Rotmann, 'The evolution of norms of protection: Major powers debate the responsibility to protect,' Global Society 30:1, 2016, pp. 3-20.

${ }^{8}$ African Union, Assembly Decision, Assembly/AU/13 (XXII), Assembly/AU/Dec.493 (XXII), 30-31 January 2014, para. 9 .

${ }^{9}$ Hettne, Björn, and Fredrik Söderbaum, 'The UN and regional organizations in global security: Competing or complementary logics?' Global Governance: A Review of Multilateralism and International Organizations 12:3, 2006, pp. 227-32.
} 
to protect is the most vivid illustration of regional multilateralism in contemporary international security governance, whose significance had been overshadowed by subsuming article 4(h) under R2P. Second, it utilizes the content analysis approach in international relations ${ }^{10}$ to translate primary data, including legal and policy documents, and academic and policy literature showing first-hand accounts of the making of the right to protect and $\mathrm{R} 2 \mathrm{P}$. This article has two main sections. The first section reviews regional and global multilateral efforts to reconcile state sovereignty with military intervention for human rights protection to underline the different logics that inspired the emergence of the right to protect and R2P. The second section reviews the AU response to $\mathrm{R} 2 \mathrm{P}$, illustrating how the primacy claim in decision-making is underpinned by continental sovereignty.

The concluding component explains the importance of this article's argument for a separate approach to implementing $\mathrm{R} 2 \mathrm{P}$ and the right to protect, instead of subordinating the latter to the former. In essence, this article favours normative pluralism over normative monism. ${ }^{11}$ By normative monism, I imply the current focus on the similarities between R2P and the right to protect, which invariably subsumes the latter under the former. By normative pluralism, I mean the overriding importance of emphasizing the variations and stressing that the right to protect and $\mathrm{R} 2 \mathrm{P}$ are independent global security norms, so that the international community, particularly the UN Security Council, can better understand the logic, objectives, and functions of the right to protect in maintaining international peace and security. This endeavour will require a study group, so I call for one to be formed.

\footnotetext{
${ }^{10}$ Hermann, Margaret M., 'Content analysis,' in Audie Klotz and Deepa Prakash, eds., Qualitative Methods in International Relations: A Pluralist Guide (London: Palgrave Macmillan, 2008), pp. 151-67.

${ }^{11}$ On the concepts of normative monism and pluralism, see Starke, Joseph G., 'Monism and dualism in the theory of international law,' in Stanley L. Paulson, Normativity and Norms: Critical Perspectives on Kelsenian Themes (Oxford: Oxford University Press, 1999), pp. 539-552; Kletzer, Christoph, 'Normative monism,' in The Idea of a Pure Theory of Law: An Interpretation and Defence (Portland: Hart Publishing, 2018), pp. 91-116; Gragl Paul, 'Introduction,' in Legal Monism: Law, Philosophy, and Politics (Oxford: Oxford University Press, 2018), pp. 4-18.
} 


\section{The Reconciliation of State Sovereignty with Military Intervention}

The section reviews the regional and global multilateral actions undertaken by the Organization of African Unity (OAU), now the AU, and the UN in the late 1990s to reconcile state sovereignty with military intervention for human rights protection or as Kofi Annan put it, 'individual sovereignty.' ${ }^{12}$ At the regional level, the OAU focused on finding ways to avoid another Rwandan genocide and acted through the International Panel of Eminent Personalities (IPEP) and the Heads of State and Government summit on OAU reforms in Sirte, Libya in 1999. The following year, the OAU Assembly, comprising Heads of State and Government of the organization's then 54 Member States adopted the IPEP report ${ }^{13}$ and agreed to include article 4(h) in the Constitutive Act, creating 'the right to intervention' in grave circumstances, such as genocide, war crimes, and crimes against humanity. At the global level, the UN responded mainly to NATO military intervention in Kosovo without the UN Security Council resolution and acted under the auspices of the International Commission on State Sovereignty and Intervention (ICISS), although an independent commission established by Canada at the request of the UN Secretary-General, Kofi Annan. The UN High-level Panel on Threats, Challenges and Change (hereafter 'High-level Panel') mandated to formulate UN reforms included the ICISS report, the 'responsibility to protect' in the recommendations. The UN General Assembly adopted the High-level Panel report in 2005, including R2P, which declared that the international community has a responsibility to intervene to prevent genocide, war crimes, crimes against humanity, and ethnic cleansing. ${ }^{14}$

\footnotetext{
12 Kofi A. Annan, 'Two concepts of sovereignty,' The Economist, 352:8137, 1991, pp. 97-98.

${ }^{13}$ International Panel of Eminent Personalities, 'Report on the 1994 genocide in Rwanda and surrounding events (selected sections),' International Legal Materials 40:1, 2001, pp. 141-235.

${ }^{14}$ International Commission on Intervention and State Sovereignty, The Responsibility to Protect (Ottawa: International Development Research Centre, 2001); United Nations, World Summit Outcome, General Assembly Resolution, A/RES/60/1, 24 October 2005, paras. 138-140. For more insights on R2P, see Evans, Gareth, and Mohamed Sahnoun, 'The responsibility to protect,' Foreign Affairs 81:6, 2002, pp. 99-110; Evans, Gareth, The Responsibility to Protect: Ending Mass Atrocity Crimes Once and For All (Washington, D.C.: Brookings Institution Press, 2009).
} 
The point is that both the regional and global efforts to reconcile state sovereignty with individual sovereignty succeeded, producing the right to protect and $\mathrm{R} 2 \mathrm{P}$, respectively. However, the logic for adopting each principle is fundamentally different, which, as we shall soon see, is the underlying factor in the dispute over primacy in decision-making in peace and security. The analysis runs in two parts. The first part focuses on the concept of regional multilateralism and the right to protect and the second part centres on the concept of global multilateralism and R2P. Regional multilateralism and global multilateralism are concepts of international security governance but operate distinct, if competing, logics.

\section{Regional Multilateralism and the Right to Protect}

This subsection evaluates the OAU-led reconciliation of state sovereignty with individual sovereignty, demonstrating that African leaders concentrated on developing a robust human rights protection principle, establishing a firm basis for the legitimacy of military intervention, and empowering the AU with an unassailable authority to protect individual sovereignty. Thus, the right to protect is the definitive reconciliation of state sovereignty with individual sovereignty, underscoring regional multilateralism in global security governance.

The concept of regional multilateralism is about the idea that regional organizations within the context of Chapter VIII of the UN Charter make rules for international peace and security governance, and so universal institutions, such as the UN Security Council can benefit regional conventions. ${ }^{15}$ However, regional norms may contrast with global principles and so

\footnotetext{
${ }^{15}$ Hettne and Söderbaum, 'The UN and regional organizations in global security'; Tardy, Thierry, 'The European Union and the United Nations: Global versus regional multilateralism,' Studia Diplomatica 60:1, 2007, pp. 191209; Acharya, Amitav, 'Post-hegemonic multilateralism,' in Weiss, Thomas G., and Rorden Wilkinson, eds., International Organization and Global Governance (London: Routledge, 2013), pp. 218-230; Ikenberry, G. John, 'The future of multilateralism: Governing the world in a post-hegemonic era,' Japanese Journal of Political Science 16:3, 2015, pp. 399-413; Recchia, Stefano, 'Overcoming opposition at the UNSC: Regional multilateralism as a form of collective pressure,' Journal of Global Security Studies 5:2, 2020, pp. 265-281; Finizio, Giovanni, 'Regional multilateralism in Africa: A system in search of rationalization,' Annali della Fondazione Luigi Einaudi 54:2, 2020, pp. 53-74.
} 
can become a problem. As Björn Hettne and Fredrik Söderbaum pointed out, regional and global approaches to international security governance may follow 'competing logics,' so one of the challenges is how to 'construct arrangements in which the two logics complement one another.' The most interesting feature of regional multilateralism is the assumption that in the future regional norms may replace universal principles because of the unrepresentative nature of global institutions. In other words, the legitimacy problem in the UN Security Council, for instance, will increasingly make regional institutions more appealing and deserving. Björn Hettne and Fredrik Söderbaum explained the concept in detail:

States and global organizations are being progressively locked into a larger regional and interregional framework in which "regions" are becoming the most relevant actors in the global security architecture. The ultimate outcome may be a "regional multilateralism" built around regional bodies such as ECOWAS [Economic Community of West African States], SADC [Southern African Development Cooperation], and the EU, as opposed to an "orthodox multilateralism" centered on the UN, with nation-states as the basic units. Regional multilateralism expresses the ambition of groups of states to control the global environment by pooling their sovereignties according to a postWestphalian logic, rather than relying on the one state one vote procedure in the UN General Assembly or the undemocratic plurilateralism ("false multilateralism") of the UN Security Council. ${ }^{16}$

Although regional multilateralism often refers to conventional regional organizations, such as the $\mathrm{AU}$ and the EU, the concept is gaining prominence in issue-specific security alliances like the Quad, involving the emerging and expanding military partnership between the United

\footnotetext{
${ }^{16}$ Hettne and Söderbaum, 'The UN and regional organizations in global security,' pp. 229-30. The emphasis is mine.
} 
States, Australia, Japan, and India. The White House press statement following a bilateral meeting between the United States President, Joe Biden, and the President of the Republic of Korea President, Moon Jae-in, noted that:

The United States and the ROK [Republic of Korea] also reaffirm support for enhanced cooperation with Pacific Island Countries and acknowledge the importance of open, transparent, and inclusive regional multilateralism including the Quad. ${ }^{17}$

Such regional security alliances, including AUKUS (Australia, United Kingdom, and the United States nuclear submarine pact), implicating P5 members in geopolitics and strategic balancing can have an unintended consequence of undermining effective global multilateralism and promoting regional multilateralism. As Ramesh Thakur and Luk van Langenhove noted, 'The major threat is that the growth of regionalism could further weaken the multilateral system and the UN [if they] create a world order based on shifting alliances between regional blocs. ${ }^{18}$ Nevertheless, this article maintains that regional multilateralism is a vital credible alternative or complementary, not a rival, system of international security governance, so that the right to protect receives independent considerations, but requires understanding the African logic and ambition that spurred African leaders to create it.

As noted earlier, African leaders, through the OAU, acted to reconcile state sovereignty with individual sovereignty and adopted the right to protect for safeguarding human rights. The international community's failure to prevent the Rwandan genocide inspired the OAU initiative. With the perception that NATO acted in Kosovo but not in Rwanda, African leaders

17 The White House, 'U.S.-ROK leaders' joint statement,' Press Briefing, 21 May 2021. <https://www.whitehouse.gov/briefing-room/statements-releases/2021/05/21/u-s-rok-leaders-joint-statement/> accessed 28 October 2021. The emphasis is mine. See also Kevin Rudd, 'Why the quad alarms China: The quad's success poses a major threat to Beijing's ambitions,' Foreign Affairs, [Snapshot], 6 August 2021, <https://www.foreignaffairs.com/articles/united-states/2021-08-06/why-quad-alarms-china> accessed 28 October 2021.

18 Thakur and Langenhove, 'Enhancing global governance through regional integration,' p. 237. 
focused on OAU reforms to create a robust principle that would enable effective interventions to prevent future occurrences. So, the logic of the OAU effort was primarily to ensure 1) a stronger response to grave situations and 2) the legality and legitimacy of military interventions. African leaders were more concerned with the legitimacy of the authorizing institution than state sovereignty. The reform and dialogue started with an OAU-authorized inquiry into the Rwandan genocide.

In June 1998, the OAU Secretary-General, Salim Ahmed Salim, established the sevenmember IPEP team to investigate the genocide in Rwanda and the surrounding events. ${ }^{19}$ The OAU mandate involved to:

investigate the 1994 genocide in Rwanda and the surrounding events, starting from the Arusha Peace Accord to the fall of Kinshasa as part of efforts aimed at averting and preventing further wide-scale conflicts in the Great Lakes Region. It is, therefore, expected to establish the facts about how such a grievous crime was conceived, planned and executed, investigate and determine culpability for the failure to enforce the Genocide Convention in Rwanda and in the Great Lakes Region, and to recommend measures aimed at redressing the consequences of the genocide and at preventing any possible recurrence of such a crime. ${ }^{20}$

African leaders focused mainly on understanding why the genocide occurred and how to prevent such future events, and IPEP reported that 'problems of inadequate capacity' was the significant cause of OAU failure and recommended that:

\footnotetext{
${ }^{19}$ OAU, Decision of the Council of Ministers, CM/DEC.409 (LXVIII), CM/2063 (LXVIII), 4-7 June 1998, paras. 2; United Nations, Letter dated 3 June 1998 from the Permanent Representative of Zimbabwe to the United Nations addressed to the President of the Security Council, Security Council, S/1998/461, annex, 3 June 1998. ${ }^{20}$ IPEP, Report on the 1994 genocide in Rwanda and surrounding events,' p. 232.
} 
Since Africa recognizes its own primary responsibility to protect the lives of its citizens, we call on: a) the OAU to establish appropriate structures to enable it to respond effectively to enforce the peace in conflict situations. $^{21}$

IPEP did not directly address the question of intervention and state sovereignty, but African leaders did during the Sirte summit on OAU reforms in September 1999, and they prioritized 1) creating a robust, indisputable legal basis for the use of force for preventing grave violations of human rights, and 2) establishing unquestionable legitimate authority for mandating military interventions for human protection. African leaders were driven by the notion of human security, the idea that the AU must centre its activities around meeting the needs of the African people. As Thomas Tieku's report on the negotiations noted, the South African President, Thabo Mbeki, proposed the concept of 'African Renaissance' - that is, popular rule involving a continental body inspired by the people's aspirations, similar to what is now known as The Africa We Want. ${ }^{22}$ Equally, the Nigerian President, Olusegun Obasanjo, submitted a similar proposal stressing human security and development as the fundamental basis for peace, security, stability, and development endeavours. ${ }^{23}$ These ideas formed the cornerstone of the revised Conference on Security, Stability, Development, and Cooperation in Africa. ${ }^{24}$ The point is that OAU reforms placed the idea of individual sovereignty at the centre.

\footnotetext{
${ }^{21}$ International Panel of Eminent Personalities, 'Report on the 1994 Genocide in Rwanda and surrounding events,' pp. 224, 229.

${ }_{22}$ The idea encapsulates 'the Pan African Vision of An integrated, prosperous and peaceful Africa, driven by its own citizens, representing a dynamic force in the international arena and Agenda 2063 is the concrete manifestation of how the continent intends to achieve this vision within a 50 year period from 2013 to 2063,' African Union, 'Agenda 2063: The Africa We Want,' 〈https://au.int/en/agenda2063/overview> accessed 31 October 2021. The emphasis is in the original text.

${ }^{23}$ Tieku, Thomas Kwasi, 'Explaining the clash and accommodation of interests of major actors in the creation of the African Union,' African Affairs 103:411, 2004, pp. 249-267.

${ }^{24}$ OAU, Solemn Declaration on Conference on Security, Stability, Development and Cooperation in Africa, Assembly Declaration, AHG/Decl.4 (XXXVI), 10 July 2000.
} 
Pertinently, the Libyan President, Mu'ammar Al-Qadhdhāfĩ, advanced the proposal on creating a robust intervention norm to empower the AU to act without the UN Security Council authorization. As Ben Kioki, former legal adviser to the AU reported, 'the necessity for the provision on intervention [article 4(h)] was premised on the original proposal by Libya to add the words "as well as in cases of unrest or external aggression in order to restore peace and stability to the Member State of the Union". ${ }^{25}$ By 'external aggression,' it implied Western intervention in Africa. In other words, the AU must have the resources to intervene adequately so Western intervention becomes redundant, and the AU need not seek authorization from the UN Security Council. Mu'ammar Al-Qadhdhāfĩ understood that to act without the UN Security Council mandate, the AU needed a firm legal basis, so he recommended the principle of continental sovereignty. Ben Kioki, quoting from the text of Al-Qadhdhāfî’s submission to the OAU Assembly, observed:

In the Explanatory Memorandum submitted by Libya, the rationale for this proposal [intervention in cases of external aggression] was given as ensuring "the sovereignty and territorial integrity of the African Continent as well as the sovereignty and territorial integrity of each Member State.”

Mu'ammar Al-Qadhdhāfí's thinking that created article 4(h) was to establish a legal right as territorial states would ordinarily possess and assert in the international system. Kioki explained that Mu'ammar Al-Qadhdhāfî intended to form a formal government and was 'not concerned about propping up unpopular regimes but rather the consequences of external aggression' and obviating the 'need for agreements with non-African states. ${ }^{26}$ So article 4(h)

\footnotetext{
${ }^{25}$ Kioko, Ben, 'The right of intervention under the African Union's Constitutive Act: From non-interference to non-intervention,' International Review of the Red Cross 85: 852, 2003, pp. 807-26, p. 811.

${ }^{26}$ Kioko, 'The right of intervention under the African Union's Constitutive Act,' pp. 811-2.
} 
is primarily about protecting right human rights and as Said Djinnit, former AU Commissioner for Peace and Security and Chief of Staff to the OAU Secretary-General, noted recently, was part of the 'compromise institutional arrangement.' 27

Essentially, the raison d'être for the right to protect is about 1) African leaders' acceptance of their past failures to forcefully respond to crises on the continent, 2) fears of nonAfrican military interventions that may be inconsistent with African priorities, and, more importantly, 3) ensuring that the Assembly is the only legitimate authority that can mandate the use of force for protecting human rights. As Ben Kioki put it, 'When setting up the African Union, the heads of State thus intended to endow their continental organization with the necessary powers to intervene if ever the spectre of another Rwandan genocide loomed on the horizon,' and so questions over 'whether the [AU] could possibly have an inherent right to intervene other than through the [UN] Security Council were dismissed out of hand. ${ }^{28}$ So, African leaders discussed relations with the Security Council and the Assembly's right to protect and decided that the former has become irrelevant especially in decision-making. Significantly, the Assembly's primacy claims today was baked into article 4(h), which provides for

The right of the Union to intervene in a Member State pursuant to a decision of the Assembly in respect of grave circumstances, namely: war crimes, genocide and crimes against humanity.

And the right to protect incorporated Mu'ammar Al-Qadhdhāfî's notion of continental sovereignty, which also underpins the Assembly's primacy assertation in decision-making on interventions, especially the use of force to protect human rights. Of course, NATO's powerful

\footnotetext{
${ }^{27}$ Said Djinnit, 'The case for updating the African Union policy on unconstitutional changes of government,' Policy and Practice Brief \#054, ACCORD, October 2021, <https://www.accord.org.za/publication/case-forupdating-au-policy-unconstitutional-changes-government/> accessed 5 November 2021.

${ }^{28}$ Kioko, 'The right of intervention under the African Union's Constitutive Act,' pp. 815, 21.
} 
example in Kosovo suggests that the Security Council's mandate may not be necessary where the purpose is to protect human rights, especially on those occasions where the Council is paralyzed due to the use of the veto by any of the P5 members. The significant difference, however, is that the notion of continental sovereignty is a challenge to the Security Council's primary responsibility for international peace and security relating to decision-making. So, the current dispute over primacy should not surprise us. The right to protect involves the legitimacy of the authorizing institution, which the AU interprets as the primacy of African institutions and decision-making.

In sum, the right to protect is the definitive outcome of African regional multilateralism in reconciling state sovereignty with individual sovereignty, and the notion of continental sovereignty answered the question of legitimate authority by establishing the Assembly's right to protect populations from genocide, war crimes, and crimes against humanity. To be clear, the concept of continental sovereignty African embedded in article 4(h) is about the Assembly's power to make decisions on interventions and not a dispute over the global primacy of the Security Council. While the original thinking about continental sovereignty was to formalize the Assembly's authority on military measures, recent developments show an expansion to underscore African priorities more broadly in decision-making (see next section for a detailed discussion). The emergence of the right to protect is the result of an exceptional regional multilateralism, independent of global multilateralism and the UN Security Council. The Assembly intended not to subordinate the right to protect to a principle (R2P) that was not yet in existence.

\section{Global Multilateralism and R2P}

This section reviews the global multilateral effort to reconcile state sovereignty with individual sovereignty. R2P is the compromise that emerged from the effort. A major highlight 
is that the R2P logic was about expunging the notion of 'a right to intervene' that involves the use of force, with or without the UN Security Council authorization, for humanitarian interventions in the global consciousness, unlike regional multilateralism and the right to protect. In substance, however, R2P remains closely tied to military force, despite a broad range of tools, including mediation, available to the Security Council. ${ }^{29}$ Crucially, the Security Council is the legitimate authority for mandating military interventions under R2P. Overall, $\mathrm{R} 2 \mathrm{P}$ is an important international security governance principle on human rights protection, underpinning successful global multilateralism.

Global multilateralism in security governance through the UN system involves cultivating a common understanding of the nature of threats to peace and order in the international system and encouraging collective action in developing and establishing ideas, norms, institutions, and practices for responding and managing such threats. Global multilateralism privileges universal rules and institutions. The hallmark is that regional organizations under Chapter VIII of the UN Charter, like the AU, merely contribute to the success of international norms and rules. As Ramesh Thakur and Luk van Langenhove put it, 'the promise is that regional organizations become a primary locus for effective action to realize the ideals of multilateralism,' because 'regional governance cannot substitute for the UN, particularly in promoting security and development in the world. ${ }^{30}$ By 'the ideals of multilateralism,' the authors mean norms and rules developed through the UN institutions,

\footnotetext{
${ }^{29}$ On mediation, see Ifediora, Obinna F., 'A regional responsibility to protect? Towards 'enhancing regional action' in Africa,' Global Responsibility to Protect 8:2-3, 2016, pp. 270-293. On the range of tools available to the Security Council, see Bellamy, Alex J., The First Response: Peaceful Means in the Third Pillar of the Responsibility to Protect (Muscatine: The Stanley Foundation, 2015).

30 Thakur and Langenhove, 'Enhancing global governance through regional integration, pp. 235, 237.' See Ruggie, John Gerard, 'Multilateralism: The anatomy of an institution,' International Organization 46:3, 1992, pp. 561-98; Barnett, Michael N., 'The United Nations and global security: The norm is mightier than the sword,' Ethics \& International Affairs 9:1, 1995, pp. 37-54; Finkelstein, Lawrence S., 'What is global governance?' Global Governance 1:3, 1995, pp. 367-372; Krahmann, Elke, 'Conceptualizing security governance,' Cooperation and Conflict 38:1, 2003, pp. 5-26; Emil J. Kirchner, 'Regional and global security: Changing threats and institutional responses,' in Kirchner, Emil J., and James Sperling, eds., Global Security Governance: Competing Perceptions of Security in the Twenty-First Century (London; New York: Routledge, 2007), pp. 3-22; Hough, Peter, Understanding Global Security (London: Routledge, 2013).
} 
including universal understandings of state sovereignty and individual sovereignty, and interventions and the $\mathrm{R} 2 \mathrm{P}$ principle.

Global multilateralism entails that threats to international peace and security must be addressed through collective efforts, preferably through the UN. So, the UN is the natural forum for the global effort to reconcile state sovereignty with individual sovereignty. For the $\mathrm{UN}$, state governments had become prime violators of human rights in their claimed efforts to maintain internal order and such actions constituted a threat to international peace and security ${ }^{31}$ requiring rethinking the idea of state sovereignty as the consolidation of the norm on non-intervention in the domestic matters of a state. The UN acted and elevated individual sovereignty above state sovereignty, raising the tension between both fundamental UN principles.

The UN debate on reconciling state sovereignty with individual sovereignty began in 1991, and the central question was under what circumstances should the international community, through the Security Council, intervene in the internal affairs of a sovereign state for the purpose of protecting human rights? The question reflected the perception that state sovereignty was at its twilight compared to individual sovereignty which was at its dawn, and the Secretary-General, Javier Pérez de Cuéllar, set the tone of the dialogue in a report to the General Assembly, arguing that 'I believe that the protection of human rights has now become one of the keystones in the arch of peace.' He further debated himself in the report, noting that:

\footnotetext{
${ }^{31}$ Mathews, Jessica Tuchman, 'Redefining security,' Foreign Affairs 68:2, 1989, pp. 162-177; Buzan, Barry, 'New patterns of global security in the twenty-first century,' International Affairs 67:3, 1991, pp. 431-451; Ann J. Tickner, 'Re-visioning security,' in Ken Booth and Steve Smith, eds., International Relations Theory Today (Oxford: Oxford University Press, 1995), pp. 175-97; Dowty, Alan, and Gil Loescher, 'Refugee flows as grounds for international action,' International Security 21:1,1996, pp. 43-71; Makinda, Samuel M., 'Sovereignty and international security: Challenges for the United Nations,' Global Governance 2:2, 1996, pp. 149-168; Buzan, Barry, Ole Wæver, and Jaap de Wilde, Security: A new framework for analysis (London: Lynne Rienner, 1998); Paris, Roland, 'Human security: Paradigm shift or hot air?' International Security 26:2, 2001, pp. 87-102; Annan, Kofi, 'In larger freedom: Decision time at the UN,' Foreign Affairs 84:3, 2005, pp. 63-74.
} 
The case for not impinging on the sovereignty, territorial integrity and political independence of states is by itself indubitably strong. But it would only be weakened if it were to carry implication that sovereignty... includes the right of mass slaughter or of launching systematic campaigns of decimation or forced exodus of civilian populations in the name of controlling civil strife or insurrection. With the heightened international interest in universalizing a regime of human rights, there is a marked and welcome shift in public attitudes. ... I would emphasize that novel doctrines are not only not required on this issue; they can also upset established understandings. It is possible that in the ongoing debate among legal experts and political theoreticians, new concepts may emerge and gain broad acceptance.

R2P did emerge 14 years later and 'upset' the conventional conception of state sovereignty but rather in a weakened form than Javier de Cuéllar anticipated: 'I am convinced that [human rights protection] involves an appropriate United Nations presence, than what was regarded as permissible under traditional international law. ${ }^{32}$ I interpret 'appropriate United Nations presence' as a forceful intervention to protect individual sovereignty that may be outside the bounds of the standard law currently in force. All this underlines the thinking among senior UN officials about creating a robust concept for human protection. The deliberation was not limited to the UN headquarters in New York; it permeated the scholarly community.

Academics and practitioners wrote about how state sovereignty was being challenged and redefined in favor of individual sovereignty. ${ }^{33}$ In many ways, Francis Deng's work on

\footnotetext{
32 United Nations, Report of the Secretary-General on the work of the organization, General Assembly, Supplement No.1, A/46/1, 13 September 1991, p. 5.

33 Chopra, Jarat, and Thomas G. Weiss, 'Sovereignty is no longer sacrosanct: Codifying humanitarian intervention,' Ethics \& International Affairs 6:1, 1992, pp. 95-117; Camilleri, Joseph A., and Jim Falk, The End of Sovereignty? The Politics of a Shrinking and Fragmenting World (Aldershot, England: Elgar, 1992); MacCormick, Neil, 'Beyond the sovereign state," The Modern Law Review 56:1, 1993, pp. 1-18; Weiss, Thomas G., 'Intervention: Whither the United Nations?' The Washington Quarterly 17:1, 1994, pp. 109-128; Weber,
} 
'reconciling sovereignty with responsibility' and later work with his colleagues on 'sovereignty as responsibility' ${ }^{34}$ set the foundation of R2P, which would 'upset established understandings.' However, China, Russia, India, Belarus, and Namibia's resistance to NATO's intervention in Kosovo in $1999^{35}$ demonstrated that scholarly advances in recharacterizing sovereignty as responsibility, non-interference as intervention, and individual sovereignty as superior to state sovereignty amounted to intellectual progress, even though NATO's action reflected Javier de Cuéllar's 'appropriate United Nations presence, than what was regarded as permissible under traditional international law' through a regional arrangement.

The practical problem, as the new Secretary-General, Kofi Annan, put it during an address to the $54^{\text {th }}$ session of the UN General Assembly, was not just about the use of force which the UN Charter allows but clarifying various elements of the concept of 'common interest' when military measures become necessary. Kofi Annan raised the following crucial questions: 'But what is that common interest? Who shall define it? Who will defend it? Under whose authority? And with what means of intervention? ${ }^{36}$ The significance of Annan's posers to the General Assembly is that sovereignty was not the main hurdle to the use of force for human rights protection. The question of legitimate authority was significant, and as we shall see in the next section, is still the single most serious wedge in the AU-Security Council relations in peace and security. For the AU, the issue of legitimate authority, which the concept

Cynthia, Simulating Sovereignty: Intervention, the State, and Symbolic Exchange (Cambridge; New York: Cambridge University Press, 1995); Lyons, Gene M., and Michael Mastanduno, eds., Beyond Westphalia? State sovereignty and international intervention (Baltimore: Johns Hopkins University Press, 1995).

${ }^{34}$ Deng, Francis M., 'Reconciling sovereignty with responsibility: A basis for international humanitarian action,' in John W. Harbeson and Donald Rothchild, eds. Africa in World Politics: Post- Cold War Challenges (Westview: San Francisco, 1995); Deng, Francis M., 'Frontiers of sovereignty: A framework of protection, assistance, and development for the internally displaced,' Leiden Journal of International Law 8:2, 1995, pp. 249-286; Deng, Francis M., Sadikiel Kimaro, Terrence Lyons, Donald Rothchild, and I. William Zartman, Sovereignty as Responsibility: Conflict Management in Africa (Washington, D.C.: Brookings Institution Press, 1996).

${ }^{35}$ United Nations, Security Council rejects demand for cessation of use of force against Federal Republic of Yugoslavia, Security Council, Press Release, SC/6659, 26 March 1999, <https://www.un.org/press/en/1999/19990326.sc6659.html> accessed 27 October 2021.

36 United Nations, Secretary-General presents his annual report to General Assembly, Press Release, SG/SM/7136, GA/9596, 20 September 1999, 〈https://www.un.org/press/en/1999/19990920.sgsm7136.html〉 accessed 27 October 2021. 
of continental sovereignty resolved in African regional multilateralism and the right to protect, is about reforming the Security Council to be more representative, an idea some scholars have called an 'illusion' or 'myths.' 37

Kofi Annan's legitimate authority riddles presaged the spirited policy dialogue across UN institutions, involving debates in the Security Council and the General Assembly sessions on reconciling state sovereignty with individual sovereignty. ${ }^{38}$ As it turned out, the Canadian response through sponsoring the ICISS was the most notable outcome of Annan's presentation of the conundrum. The ICISS mandate involved finding 'new ways of reconciling the seemingly irreconcilable notions of intervention and state sovereignty' and developing 'a global political consensus on how to move from polemics - and often paralysis - towards action within the international system, particularly through the United Nations,' but the core directive centred on the use of force for human rights protection, thus:

The kind of intervention with which we are concerned in this report is action taken against a state or its leaders, without its or their consent, for the purposes which are claimed to be humanitarian or protective. By far the most controversial form of such intervention is military, and a great part of our report necessarily focuses on that. ${ }^{39}$

The Commission reported on some concerns about language becoming an obstacle to focusing on substantive issues, such as the legitimate authority question. The ICISS's worry about

\footnotetext{
${ }^{37}$ Weiss, Thomas G., 'The illusion of UN Security Council reform,' Washington Quarterly 26:4, 2003, pp. 147161; Hurd, Ian, 'Myths of membership: The politics of legitimation in UN Security Council reform,' Global Governance 14:2, 2008, 199-217.

${ }^{38}$ United Nations, $12^{\text {th }}$ plenary meeting, General Assembly, A/54/PV.12, 24 September 1999; United Nations, Importance of state sovereignty, need to address human rights violations, Council reform, discussed in Assembly, General Assembly, Press Release, GA/9633, 8 October 1999, $\langle$ https://www.un.org/press/en/1999/19991008.ga9633.doc.html> accessed 27 October 2021; United Nations, Security Council debate said to help in creating "ethos of conflict prevention"”, support for intervention, Security

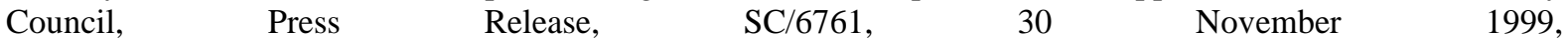
https://www.un.org/press/en/1999/19991130.sc6761.doc.html> accessed 27 October 2021.

${ }^{39}$ ICISS, The Responsibility to Protect, pp. 8, 81.
} 
terminology underpinned a crucial logic for abandoning the notion of a 'right to protect' and embracing a 'responsibility to protect' framing. The Commission suggested that the 'continuing fears about a "right to intervene" being formally acknowledged' was the reason for adopting a 'responsibility to protect' expression. Remarkably, the Commission stated that 'the "responsibility to protect" is more of a linking concept that bridges the divide between intervention and sovereignty; the language of the "right or duty to intervene" is intrinsically more confrontational,' and that 'a "right to intervene" by one state on the territory of another state is outdated and unhelpful. ${ }^{40}$ The Commission's rationale is inconsistent with the logic of the right to protect ('the right of the [African] Union to intervene') established in article 4(h) of the Constitutive Act. Instead, African leaders worried and still worry (see next section for detail) about the legitimacy of the UN Security Council, which the AU perceived as a relic of colonialism because of the P5's lack of inclusion and diversity, not about a language the Commission thought was 'outdated and unhelpful.' On the contrary, the AU embraced 'the confrontational' expression and established 'the right to intervene.' On substance, for the ICISS, there was no adequate alternative to the Security Council as the legitimate authority. However, that the Council could lose credibility if it failed to act, and regional agencies may act in the Council's absence. ${ }^{41}$

Lastly, the UN General Assembly endorsed the non-confrontational term, the 'responsibility to protect,' at the 2005 World Summit. Strangely, the General Assembly placed R2P under the broad theme on 'human rights and the rule law' instead of 'peace and collective security, ${ }^{, 42}$ which the debate on state sovereignty and intervention had been largely conducted. One explanation being advanced by this article is that a 'responsibility to protect' framing did

\footnotetext{
${ }^{40}$ ICISS, The Responsibility to Protect, pp. 11, 17.

${ }^{41}$ ICISS, The Responsibility to Protect, pp. 47-55. See also Thakur, Ramesh, 'Outlook: Intervention, sovereignty and the responsibility to protect: Experiences from ICISS,' Security Dialogue 33:3, 2002, pp. 323-340.

${ }^{42}$ United Nations, World Summit Outcome, Part IV, paras. 138-140.
} 
not reconcile Member States' (especially the AU) security concerns. For example, the answer to Kofi Annan's question of legitimate authority, which is central to the dispute with the AU, was mostly unanswered as the resolution rightly reaffirmed the Security Council's primacy, ${ }^{43}$ but Annan found solace in the fact that R2P was 'generally accepted at last. ${ }^{, 44}$ Indeed, global multilateralism in reconciling state sovereignty with individual sovereignty succeeded and produced R2P. As Anne-Marie Slaughter put it, R2P is the 'most important shift in the definition of sovereignty since the Treaty of Westphalia. ${ }^{\text {'45 }}$ The UN Secretaries-General, Ban Ki-moon and António Guterres, as well practitioners and academics have reported on the progress in implementing R2P. ${ }^{46}$ However, R2P is yet to solve the Security Council's twin problems of paralysis, as the situations in Syria and Myanmar show, and legitimacy in the context of AU relations, exacerbated by NATO's expanded action in Libya.

In sum, and fundamentally, this section has demonstrated that the regional and global multilateralisms in reconciling state sovereignty with intervention to protect human rights succeeded in producing two distinct international security regimes, although sharing similar history and goals. The right to protect and R2P emerged from separate, if competing, logics of regional versus global multilateralism, and so neither can effectively replace or subsume the

\footnotetext{
${ }^{43}$ For helpful insights on the problem of international authority and legitimacy, see Hurd, Ian, 'Legitimacy and authority in international politics,' International Organization 53:2, 1999, pp. 379-408; Orford, Anne, International Authority and the Responsibility to Protect (Cambridge: Cambridge University Press, 2011); Zürn, Michael, Martin Binder, and Matthias Ecker-Ehrhardt, 'International authority and its politicization,' International Theory 4:1, 2012, pp. 69-106.

44 Kofi A. Annan, 'A glass at least half-full,' Wall Street Journal, $<$ https://www.wsj.com/articles/SB112708454142944392> accessed 27 October 2021. For some insights into the negotiations leading the endorsement of the R2P norm, see Wheeler, Nicholas J., 'A victory for common humanity: The responsibility to protect after the 2005 World Summit,' Journal of International Law and International Relations, 2:1, 2005, pp. 95-107; Bellamy, Alex J. 'Whither the responsibility to protect? Humanitarian intervention and the 2005 World Summit,' Ethics \& International Affairs 20:2, 2006, pp. 143-169. 45 Slaughter, Anne-Marie, 'The Robert L. Levine distinguished lecture series - A new UN for a new century,' Fordham Law Review 74:6, 2006, pp. 2961-2970, p. 2964.

${ }^{46}$ United Nations, Implementing the responsibility to protect: Report of the Secretary- General, General Assembly, A/63/677, 12 January 2009; United Nations, Responsibility while protecting: Elements for the development and promotion of a concept, General Assembly, A/66/551-S/2011/701, 11 November 2011; Thakur, Ramesh, 'R2P after Libya and Syria: Engaging emerging powers,' The Washington Quarterly 36:2, 2013, pp. 6176; United Nations, Advancing atrocity prevention: Work of the Office on Genocide Prevention and the Responsibility to Protect, Report of the Secretary-General, General Assembly and Security Council, A/75/863S/2021/424, 3 May 2021.
} 
other, but for practical purposes, one must have primacy in interventions, and that is a major cause of the problem in the Security Council-AU relations. The AU primacy claims reflect the logic of regional multilateralism and the right to protect, despite not contesting the Security Council's primary responsibility for international peace and security. Table I illustrates the key differences between the right to protect and R2P.

Table I. Key Differences between the Right to Protect and the Responsibility to Protect

The Right to Protect

The legitimate authority is the Assembly
The Responsibility to Protect

The legitimate authority is the Security Council
Based on a legal commitment

Disallows pre-emptive use of force

Involves genocide, war crimes, and crimes against humanity

Protection responsibility is regional, consistent with the AUled regional multilateralism
Based on a political commitment

Allows pre-emptive use of force

Includes genocide, war crimes, crimes against humanity, and ethnic cleansing

Protection responsibility is global, consistent with the UN-led multilateralism

The point is that the right to protect and $\mathrm{R} 2 \mathrm{P}$ contribute in distinct ways to strengthening and enriching international security regimes on human rights protection, underpinning this article's emphasis on normative pluralism - by which I mean the perspective that highlights the importance of embracing different ideas with similar goals and creating alternatives that promote the Security Council's flexibility and effectiveness, as Figure I show. 


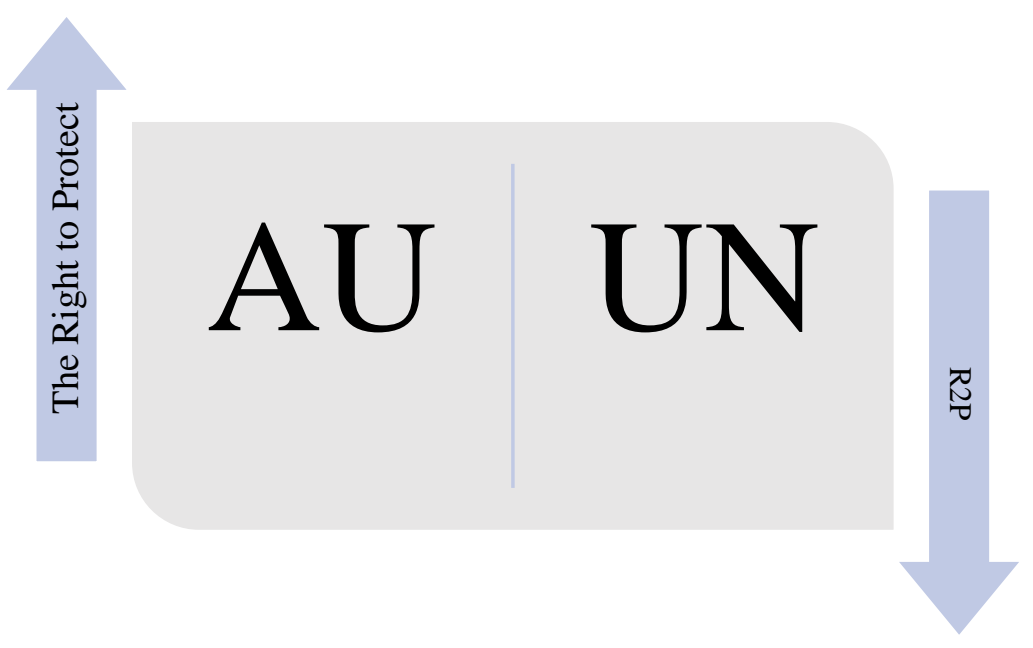

Figure I. Alternative International Security Regimes on Human Rights Protection

The right to protect moves toward the globe and R2P moves toward the regions and both must boost a pluralist international security framework. As this article argues, the right to protect can address the twin problems of legitimacy and veto-induced paralysis in the Security Council, and not just in Africa but globally, but it entails that the Security Council must embrace the Assembly's primacy and continental sovereignty claims - the idea is a hard sell indeed, although not impossible. The reality is that both security regimes tend to clash, creating the practical problem between the AU and the Security Council over primacy.

\section{Continental Sovereignty: The AU Response to R2P}

This section reviews AU policy engagement with R2P since the General Assembly endorsed the principle in the World Summit Outcome in 2005. Put simply, the AU has rejected R2P because of the legality and legitimate authority questions but seeks to influence the Security Council reforms so that the decision-making mechanism in the P5 system reflects the AU method. Moreover, the AU asserts the right to protect, indicating that the Security Council can only use military force to protect human rights under article 4(h), which means through the Assembly's legitimate authority and primacy. In essence, the AU is actively advancing the 
continental sovereignty concept - that is, the Assembly's primacy in decision-making on the use of force for human rights protection. Interestingly, the continental sovereignty claim features in the broader AU-Security Council relations in peace and security, particularly in pursuing international criminal justice, a major component of $\mathrm{R} 2 \mathrm{P}$. The AU response underscores the 'competing logics' of the right to protect and R2P (see the previous section) and underlines the importance of thinking about the Security Council's role in implementing the regional human rights protection regime.

The official AU response to R2P is contained in the Common African Position on the Proposed Reform of the UN, otherwise known as the Ezulwini Consensus, the name of the city in the Kingdom of Eswatini where it was adopted. The Executive Council of the AU adopted the Ezulwini Consensus in 2005, and the Assembly has consistently reaffirmed the validity of the policy. ${ }^{47}$ The Ezulwini Consensus addressed specifically the 2004 report of the UN Highlevel Panel on Threats, Challenges and Change about the necessary institutional reforms of the UN that would encourage effective management of collective security problems in the twentyfirst century, which included the ICISS report on R2P. So, the AU's engagement with R2P is the ICISS version as incorporated into the High-level Panel's report, not the thin edition adopted by the UN General Assembly in the World Summit Outcome document. Notably, the High-level Panel report discussed R2P within the context of collective security and the use of force, specifically article 51 of the UN Charter on self-defence and other military authorizations by the Security Council under Chapter VII, including R2P, and examined the two crucial questions of legality and legitimacy. ${ }^{48}$

\footnotetext{
${ }^{47}$ African Union, The common African position on the proposed reform of the United Nations: "The Ezulwini Consensus," Ext/EX.CL/2 (VII), 7-8 March 2005, p. 6. The Assembly endorsed the Ezulwini Consensus in Sirte Declaration in 2005, African Union, Sirte Declaration on the Reform of the United Nations, Assembly/AU/Decl. 2 (V), 4-5 July 2005, and has repeatedly did so since then, including recently, see African Union, Assembly Decision, Assembly/AU/Dec.766 (XXXIII), 09-10 February 2020, para. 7

${ }^{48}$ United Nations, A more secure world: Our shared responsibility: Report of the high-level panel on threats, challenges and change, annex, General Assembly, A/59/565, 2 December 2004, paras. 183-209.
} 
The Ezulwini Consensus preceded the World Summit in 2005, so the AU intended to inspire UN reforms and global multilateralism, noting that 'Africa is now in a position to influence the proposed UN reforms, ${ }^{49}$ but the Assembly failed. Pertinently, unlike the World Summit Outcome document where the General Assembly placed R2P within the broad theme on Human Rights and the Rule of Law, the Executive Council of the AU located the Assembly's reply in the Collective Security and the Use of Force section of the Ezulwini Consensus policy instrument, thereby aligning with the High-level Panel's thinking and indicating unambiguously that military intervention for human rights protection is a serious security matter. Although the AU generally considered the High-level Panel's proposed use of force criteria, it rejected the ICISS's reconciliation of state sovereignty with intervention, arguing that 'It is important to reiterate the obligation of states to protect their citizens, but this should not be used as a pretext to undermine the sovereignty, independence and territorial integrity of states.' However, the real problem is not state sovereignty, which the AU had qualified by establishing the right to protect; rather, the AU was concerned with questions of legitimacy and legality relating to the authorizing institution and the protection regime. As the AU Executive Council noted:

With regard to the use of force, it is important to comply scrupulously with the provisions of Article 51 of the UN Charter, which authorise the use of force only in cases of legitimate self-defence. In addition, the Constitutive Act of the African Union, in its Article 4 (h), authorises intervention in grave circumstances such as genocide, war crimes and crimes against humanity. Consequently, any recourse to force outside the framework of Article 51 of the UN Charter and Article 4 (h) of the AU Constitutive Act, should be prohibited. Furthermore, it is important

\footnotetext{
${ }^{49}$ African Union, The common African position on the proposed reform of the United Nations, Part C, p. 9.
} 
to define the notion of "collective danger" which would justify collective action. ${ }^{50}$

The AU policy as outlined in the above text is that article 4(h) is the only legal provision on which decisions relating to the use of force for protecting human rights must be based, so this is an invitation by the AU to the UN Security Council to consider its role under the right to protect. Otherwise, the AU perceives the use of force under any other concept or principle as illegal and illegitimate because that would amount to a violation of continental sovereignty, the new principle underpinning the Assembly's primacy claim in decision-making on interventions. In addition, the Executive Council raised the question of 'collective danger' or what Kofi Annan called 'collective interest' in the context of who should define the concept. This points to the issue of the legitimacy of the Security Council because of the P5's lack of representation, inclusion, and diversity. The Executive Council noted that:
Africa's goal is to be fully represented in all the decision- making organs of the UN, particularly in the Security Council, which is the principal decision-making organ of the UN in matters relating to international peace and security. ${ }^{51}$

Full representation means two permanent seats and the right of veto, which the AU opposes in principle. ${ }^{52}$ In essence, the AU rejected R2P because of the twin questions of legitimacy and legality surrounding the UN Security Council, which Kofi Annan had raised during the address to the General Assembly. Several senior AU officials have elaborated on both issues.

The former Chairperson of the AU Commission, Jean Ping, discussed the matters of legitimacy and the legality of the Security Council's actions under Chapter VII in a keynote

\footnotetext{
${ }^{50}$ African Union, The common African position on the proposed reform of the United Nations, Part B, p. 6.

${ }^{51}$ African Union, The common African position on the proposed reform of the United Nations, Part C, p. 9.

${ }^{52}$ African Union, The common African position on the proposed reform of the United Nations, Part C, p. 9.
} 
address to the expert roundtable on the Responsibility to Protect and Genocide Prevention in Africa, jointly organized by the International Peace Institute, InterAfrica Group, and the UN Office of the Special Adviser on the Prevention of Genocide in October 2008. He recalled African states' concern with 'the role of the UN Security Council' and 'the possibility of abuse of the responsibility to protect.' Crucially, he pointed out that 'The sense of ownership that AU member states have in their own institutions is not replicated in respect of UN member states vis-à-vis UN Security Council because of the right of veto and the role of the P5.' Here, Jean Ping made a clear distinction between AU and UN institutions, which explains why the Assembly has confidence in African institutions and challenges the Security Council's legitimacy.

Pertinently, Jean Ping raised several critical questions over whether the AU-led international mediation of Kenya's post-election violence in 2008 amounted to an R2P intervention to underline AU policy on R2P. One of the significant questions is: 'Did the Kenyan situation fall within the classic case of a government that CANNOT protect its population, or is UNABLE to do so, or is PARTICIPATING in the situation?'53 Notably, the question aligns with the relevant Assembly decisions on the AU intervention, which stressed that the goal was to restore 'peace and stability' and address 'gross violation of human rights' through 'investigation and prosecution. ${ }^{54}$ The Assembly's decision did not refer to 'grave circumstances' as anticipated in article 4(h).

As the Chairperson of the AU Commission making remarks in his official capacity, the reasonable inference is that Jean Ping's views reflected the prevailing thinking among senior AU officials about R2P in Africa. In addition, given the provisions of the Ezulwini Consensus

\footnotetext{
${ }^{53}$ Ping, Jean, 'The responsibility to protect in Africa: Keynote address by the Chairperson of the African Union Commission,' in Jenna Slotin, Castro Wesamba, and Teemt Bekele, rapporteurs, The Responsibility to Protect and Genocide Prevention in Africa (Washington, D.C.: International Peace Institute, 2009), pp. 11-14, pp. 11-13. ${ }^{54}$ African Union, Assembly Decision, Assembly/AU/Dec. 187 (x), 31 January - 2 February 2008, paras. 1-3.
} 
rejecting $\mathrm{R} 2 \mathrm{P}$ and asserting the right to protect, the address should not be overly surprising. Particularly, the Chairperson reasoned that if the case of Kenya represented an R2P event, as most scholars, analysts, advocates, and policymakers, including Kofi Annan, ${ }^{55}$ already determined, then there are no limits to labelling violent situations as R2P that would then necessitate the use of force. The relevance of Jean Ping's observation is that the R2P bar on military intervention was too low compared to the right to protect. Jean Ping contrasted the regional multilateralism that produced the right to protect with global multilateralism that created R2P to stress the higher African standard in the context of global security governance, thus:

It should nevertheless be pointed out that the approach at the level of the continent provided safeguards, in that intervention could only be authorized by the Assembly of the Union or the Peace and Security Council and, secondly, only in grave circumstances, such as genocide, war crimes, and crimes against humanity. ${ }^{56}$

There are two salient components of the Chairperson's discussion. The first component implies the checks and balances that African leaders weaved into the right to protect and the AU system, reinforcing the notion of continental sovereignty in the sense that the power for mandating a legally grounded military intervention resides with the Assembly whose legitimacy is anchored in the collective ownership of AU institutions by African states and the democratic nature of the decision-making procedure in AU organs. ${ }^{57}$

\footnotetext{
${ }^{55}$ Annan, Kofi A., Interventions: A Life in War and Peace. (New York: Penguin, 2012), pp. 184-201. See also Weiss, Thomas G., 'Halting atrocities in Kenya,' Great Decisions 2010, pp. 17-30. For a helpful contrasting perspective, see O'Connell, Mary Ellen, 'Responsibility to peace: A critique of R2P,' Journal of Intervention and Statebuilding 4:1, 2010, pp. 39-52.

${ }^{56}$ Ping, 'The responsibility to protect in Africa,' p. 11.

${ }^{57}$ The AU makes critical decisions on peace and security are through consensus, or by two-thirds majority of the 15-member Peace and Security Council or the 55 Heads of State and Government. For more discussion of the checks and balances in the AU system, see Kioki, 'The right of intervention under the African Union's Constitutive Act.'
} 
The second component reiterates the right to protect's higher threshold. R2P allows pre-emptive military intervention, like NATO action in Libya. The ICISS report stipulated that 'the just cause threshold' involves 'large scale loss of life, actual or apprehended.' Likewise, the High-level Panel report specified the condition of the 'seriousness of threat. ${ }^{, 58}$ On the other hand, the right to protect requires actual 'grave circumstances' before the Assembly considers authorizing the use of force. A good example is the case of Burundi in 2016. The Assembly decided against the recommendation of the Peace and Security Council to authorize the African Prevention and Protection Mission in Burundi. The Peace and Security Council had based the recommendation on the report of the African Commission on Human and People's Rights that found gross and systematic violations of human rights by the government of Burundi. Instead of mandating the use of force, the Assembly decided in favour of regional diplomacy and authorized a High-level delegation of Heads of State and Government to mediate the crisis. ${ }^{59}$

The AU response to R2P must be distinguished from some African states who directly engage with the ongoing efforts to further develop and build broader acceptance of R2P, particularly through deputations to the UN General Assembly annual debate. The AU does not engage in the debate, although it has a ten-member Permanent Representative Committee of diplomats accredited to the UN. Nevertheless, the AU plays a crucial role in the global dialogue on the reform of the UN system, particularly the Security Council. The Assembly's policy as outlined in the Ezulwini Consensus is that the decision-making mechanism in the Security Council, particularly the use of the veto power is sometimes unhelpful in promoting consensus, a vital feature of the AU method of making serious decisions on peace and security challenges

\footnotetext{
${ }^{58}$ ICISS, The Responsibility to Protect, p. XII; United Nations, A more secure world, para. 207.

${ }^{59}$ African Union, Assembly Communiqué, PSC/AHG/COMM.3 (DLXXI) 29 January 2016, p.13; African Union, the Peace and Security Council Communiqué, PSC/PR/COMM.(DLXV), 17 December 2015. For an insightful review of the Assembly decision-making process and the analysis that referenced the ICISS version of R2P, see Dersso, Solomon, 'To intervene or not to intervene? An inside view of the AU's decision-making on Article 4 (h) and Burundi,' Occasional Paper, World Peace Foundation, 26 February 2016,

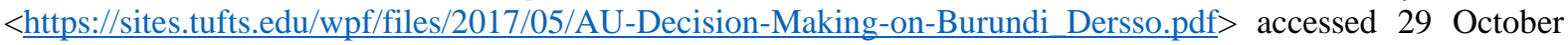
2021.
} 
on the continent. Accordingly, the Ezulwini Consensus is about promoting dialogue and consensus in the Security Council, especially on decisions relating to military intervention for human protection. The Ezulwini Consensus responds primarily to the use of force for human rights protection, otherwise known as 'Pillar three' of R2P. ${ }^{60}$ The significance is that despite the failure to influence the outcome of the World Summit in 2005, the Assembly has continued endorsing the Ezulwini Consensus, underscoring the persistence of the influence campaign. In other words, the AU is not averse to the UN Security Council using military force in Africa but stresses continental sovereignty - that the Assembly is the only legitimate authority, and that the applicable regime is the right to protect with adequate 'safeguards.'

The AU influence project focusing on promoting dialogue and consensus in the UN Security Council through the Assembly's continuing validation of the Ezulwini Consensus illustrates the Assembly's principled opposition to the veto power, which often causes paralysis. The policy is that the veto power should be abolished but, if it remained, then Africa should be accorded the full privileges and responsibilities. ${ }^{61}$ From this perspective, the policy is consistent with the views of former President of France, François Hollande, who proposed for a collective renunciation of the use of veto:

The UN has a responsibility to take action. And whenever our organization proves to be powerless, it's peace that pays the price. That's why I am proposing that a code of good conduct be defined by the permanent members of the Security Council, and that in the event of a mass crime they can decide to collectively renounce their veto powers. ${ }^{62}$

\footnotetext{
${ }^{60}$ United Nations, Implementing the responsibility to protect, Report of the Secretary-General, General Assembly, A/63/677, 12 January 2009, paras. 49-66. However, Pillar Three involves peaceful means, like mediation, see Bellamy, 'The first response'; Ifediora, 'A regional responsibility to protect?'

${ }^{61}$ African Union, The common African position on the proposed reform of the United Nations, Part C, p. 9

${ }^{62}$ François Hollande, 'Opening of the 68th session of the United Nations General Assembly - Statement by Mr. François Hollande, President of the Republic,' Permanent Mission of France to the United Nations, 24 September 2013, <https://onu.delegfrance.org/24-September-2013-Opening-of-the> accessed 27 October 2021.
} 
The idea is that decisions on authorizing the use of force for human protection should be by consensus, either by two-thirds or by a simple majority of the fifteen-member Security Council. This would bring the required votes for Chapter VII resolutions in line with the AU voting method, effectively ensuring the Assembly's full participation in the Security Council decisionmaking as well as advancing the legitimacy of the Council. Pertinently, AU's insistence that Chapter VII decisions must be reached through consensus underlines effort to change how the Security Council does the business of peace and security and reflects a demand to respect continental sovereignty in making decisions on interventions. In sum, the Ezulwini Consensus on AU's response to R2P is not an endorsement ${ }^{63}$ but a rejoinder outlining further necessary development, without which the Assembly will keep the present distance with the global regime. As Jean Ping, put it, 'the concerns that were expressed by many states during the consideration of the [World Summit] Declaration are still valid and cannot be ignored. ${ }^{64}$ The case of Libya, where the Assembly opposed the use of force and insisted on regional diplomacy against the Security Council-authorized NATO military action, supports AU policy on R2P and continental sovereignty claim.

Thus far this analysis of AU's response to R2P has revolved around the Assembly's claim to continental sovereignty as embedded in article 4(h), focusing on the use of force to protect human rights. However, recent continental sovereignty claims extend to all dimensions of the AU-Security Council relations in peace and security, particularly in the context of pursuing international criminal justice, involving investigation and prosecution through the ICC. International criminal justice is a major component of R2P and is one of those nonmilitary measures Chapter VII of the UN Charter contemplated. The ICC investigation and warrant of arrest against former President Omar al-Bashir of Sudan is what triggered the Assembly's

\footnotetext{
${ }^{63}$ On this point, see Bellamy, Alex J., 'Whither the responsibility to protect? Humanitarian intervention and the 2005 World Summit,' Ethics \& International Affairs 20:2, 2006, pp. 143-169.

${ }^{64}$ Ping, 'The responsibility to protect in Africa,' p. 13.
} 
official continental sovereignty claim. ${ }^{65}$ So, the concept of continental sovereignty is now the AU policy underpinning the primacy assertation.

The Security Council, acting under Chapter VII of the UN Charter, determined 'that the situation in Sudan continues to constitute a threat to international peace and security' and referred the genocidal conflict in Darfur to the ICC. Given that violence and atrocities were still occurring at the time of the referral and that the measure was taken under Chapter VII, the ICC involvement amounted primarily to a measure short of force to protect human rights, and yet the AU opposed the action and asserted continental sovereignty. Notably, the Security Council considered a regional approach to ensuring justice and invited:

the Court and the African Union to discuss practical arrangements that will facilitate the work of the Prosecutor and of the Court, including the possibility of conducting proceedings in the region, which would contribute to regional efforts in the fight against impunity. ${ }^{66}$

However, following the ICC Prosecutor's application for an arrest warrant against President al-Bashir on 14 July 2008, the AU responded a week later, demanding the priority of mediation to ensure peace and stability and expressed the commitment to fight impunity. In the initial request to the UN Security Council to defer the proceedings under article 16 of the Rome Statute, the AU Peace and Security, with subsequent endorsements by the Assembly, stressed 'the need to ensure that the ongoing peace efforts are not jeopardized ${ }^{67}$ by the Prosecutor's action. The UN Security Council replied on 31 July 2008 and reiterated 'that the situation continues to constitute a threat to international peace and security' and noted the Council's

\footnotetext{
${ }^{65}$ Also, the Assembly's continental sovereignty claim related to the ICC charges against President Uhuru Kenyatta and his deputy, William Ruto, concerning the crimes against humanity committed during the post-election violence in Kenya between 2007 and 2008.

${ }^{66}$ United Nations, Security Council Resolution, S/RES/1593 (2005), 31 March 2005, paras. 1, 3, and the preamble. ${ }^{67}$ African Union, Peace and Security Council Communiqué, PSC/MIN/Comm (CXLII), 21 July 2008, para. 11. African Union, Assembly Decision, Assembly/AU/Dec.221(XII), 1 - 3 February 2009, para. 3.
} 
'intention to consider these matters further. ${ }^{68}$ However, the dispute over primacy was never resolved, resulting in the Assembly's formal continental sovereignty claim and the right to defend it by any decisions and measures necessary. In the pivotal decision in 2014, the Assembly underlined:

the need for the UN Security Council to reserve a timely and appropriate response to requests made by the $\mathrm{AU}$ on deferral in accordance with Article 16 of the Rome Statute under Chapter VII of the UN Charter so as to avoid the sense of lack of consideration of a whole continent.

Otherwise, the Assembly:

DECIDES that the African Union and its Member States, in particular the African States Parties to the Rome Statute, reserve the right to take any further decisions or measures that may be necessary in order to preserve and safeguard peace, security and stability, as well as the dignity, sovereignty and integrity of the continent. ${ }^{69}$

The Assembly's declaration of the right to 'preserve and safeguard' continental sovereignty refers to decision-making on peace, security, and stability, implying that the Security Council was already violating the sovereignty of the continent, and so the Assembly retains the right to prevent further infringements. Notably, the idea of continental sovereignty is an unprecedented claim by a non-state actor in the international system with significant theoretical and practical questions, albeit outside the current article's focus. It suffices to say that some scholars have been anticipating that the EU would be the first non-state actor to declare sovereignty. ${ }^{70}$

\footnotetext{
${ }^{68}$ United Nations, Security Council Resolution, S/RES/1828 (2008), 31 July 2008, the preamble.

${ }^{69}$ African Union, Assembly Decision, Assembly/AU/13(XXII), 30-31 January 2014, paras. 8-9. See also African Union, Assembly Decision, Assembly/AU/Dec.547(XXIV), 30-31 January 2015, para. 17(c).

${ }^{70}$ Wæver, Ole, 'Identity, integration and security: Solving the sovereignty puzzle in EU studies,' Journal of International Affairs 48:2, 1995, pp. 389-431; Werner, Wouter G., and Jaap H. de Wilde, 'The endurance of
} 
The Security Council did not comply with the Assembly's demands to defer the referral of the Darfur situation to the ICC, triggering a chain of decisions and measures by the Assembly to defend continental sovereignty. In June 2014, the Assembly adopted the Protocol on the Amendment to the Statute of the African Court of Justice and Human Rights (the new court would be the African Court on Human and People's Rights) including a provision in article 46 that grants immunity to the sitting Heads of State and Government and other senior officials from prosecution - in the previous decision of January 2014 quoted above, the Assembly had requested the AU Commission 'to speed up' the amendment process. ${ }^{71}$ A year later, the AU established the Open-ended Ministerial Committee of Ministers of Foreign Affairs on the ICC to develop strategies for the implementation of Assembly decisions on the ICC, including the deferral request to the Security Council. ${ }^{72}$ In January 2016, following expression of 'deep grieve at the failure of the UNSC to respond to the requests of the AU for deferral of The Sudan case [and others],' the Assembly asked the Open-ended Ministerial Committee to formulate 'a comprehensive strategy [for] collective withdrawal from the ICC. ${ }^{, 73}$

The Open-ended Ministerial Committee developed the Withdrawal Strategy Document, which the Assembly adopted in January 2017. In substance, the Withdrawal Strategy Document was an influence campaign, just like the Ezulwini Consensus. It noted that the objective of the AU policies on the ICC includes 1) ensuring that international justice is conducted in a fair and transparent manner devoid of any perception of double standards, 2) instituting legal and administrative reforms of the ICC, 3) enhancing the regionalization of

sovereignty,' European Journal of International Relations 7:3, 2001, pp. 283-313; Schmidt, Vivien A., 'The European Union: Democratic legitimacy in a regional state?' Journal of Common Market Studies 42:5, 2004, pp. 975-97; Schmidt, Vivien A., Conceptualizing Europe as a 'region-state', in Anthony Petros Spanakos and Francisco Panizza, eds., Conceptualising Comparative Politics (New York: Routledge, 2016), pp. 17-45.

71 African Union, Assembly Decision, Assembly/AU/8(XXIII), 26-27 June 2014, para. 2; African Union, Assembly Decision, Assembly/AU/13(XXII), 30-31 January 2014, para. 13.

72 African Union, Assembly Decision, Assembly/AU/Dec. 586 (XXV), 14-15 June 2015, para. 4. See also the earlier decision adopted in January 2015, African Union, Assembly Decision, Assembly/AU/Dec.547(XXIV), 3031 January 2015, para. 17 (d-e).

${ }^{73}$ African Union, Assembly Decision, Assembly/AU/Dec.590(XXVI), 30 - 31 January 2016, paras. 8, 10(iv). 
international criminal law, and 4) preserving the sovereignty of Member States. The idea of regionalizing international criminal law in Africa is in line with regional multilateralism leading to the adoption of the Malabo Protocol in 2014, albeit with the backward-looking immunity for serving Heads of State and Government and other senior officials.

Crucial for underscoring the influence project tenor of the Withdrawal Strategy Document, the Open-ended Ministerial Committee, drawing on Lawrence Helfer's work on exiting and terminating treaties, indicated that the Assembly's thinking about the so-called 'collective withdrawal' was to 'challenge and objurgate' the ICC and 'propose different legal alternatives' to the Rome Statute in the sense of normative pluralism. Of course, the Malabo Protocol is one option to the Rome Statute, just like the right to protect is an alternative to R2P. So, at the heart of the collective withdrawal strategy was 'increasing [the Assembly's] leverage to reshape the treaty [the Rome Statute and Rules of Procedure] to more accurately reflect its interests or [establish] a rival legal norm, ${ }^{74}$ in the sense of the Malabo Protocol. Like the Ezulwini Consensus, the Withdrawal Strategy Document as an influence campaign also failed, as the Security Council ignored the deferral request. However, the significance of the withdrawal strategy is underpinning the Assembly's defence of continental sovereignty, which is currently about primacy in decision-making on peace and security - a defence of an extraordinary concept of sovereignty not yet backed by real power.

\section{Conclusion}

The UN Security Council-AU relations in peace and security, especially in the implementation of the $\mathrm{R} 2 \mathrm{P}$ principle, has been problematic and will likely remain so in the foreseeable future. Despite existing assumptions about the compatibility of the $\mathrm{R} 2 \mathrm{P}$ and the right to protect

\footnotetext{
74 African Union, Assembly Decision, 'Withdrawal Strategy Document, annex, Assembly/AU/Dec.622(XXVIII), 30 - 31 January 2017, paras. 8, 19-20.
} 
regimes, resulting in subsuming the latter in the former, the dispute over primacy is real, and is having a substantial practical impact on the effectiveness of joint interventions - from the Security Council-authorized military intervention in Libya to the referral of the genocidal conflict in Sudan to the ICC, the AU opposed these measures and mounted vigorous political, diplomatic, and legal challenges to the Council's authority. ${ }^{75}$ These concrete difficulties conjure the perception that the window of cooperation may be closing instead of opening, forcing us to accept that it was time we rethought current presumptions and understandings, and abandon the current normative monist approach to the problem. This article has done exactly that, thereby initiating a different channel of inquiring into solutions to the dispute.

This study establishes the dynamic perspective for fresh thinking about the cold AUSecurity Council relations in peace and security by taking a normative pluralist view and introducing the concept of regional multilateralism, whose influence in contemporary security policy and practice is only rapidly growing, to the conversation. This new approach responds to the current international security landscape that is witnessing the presence of diverse actors with real potential to strengthen or disrupt global peace, security, and stability. The diversity of players underscores the multipolar security environment facing us today and will still confront us tomorrow and demands we look harder to understand the truer character of each actor's resources to appreciate better how to adapt such powers to effectively maintain global peace and security.

The AU presently lacks tangible power and resources but possesses the most robust human rights protection regime than any other actor in the international system. The right to protect is the most sophisticated human protection principle currently existing in the repertoire

\footnotetext{
${ }^{75}$ The AU Assembly submitted a request asking the UN General Assembly to seek an advisory opinion of the International Court of Justice on the matter, see United Nations, 'Request for an advisory opinion of the International Court of Justice on the consequences of legal obligations of States under different sources of international law with respect to immunities of Heads of State and Government and other senior officials,' General Assembly, A/73/144, 18 July 2018.
} 
of global human rights protection regimes. The right to protect is a legal right endowed with an unimpeachable legitimacy and authority for implementation. While the logic of the right to protect is fundamentally different, it need not contradict R2P and other international principles. The most significant question now, which I do not have any answer to, is how the UN Security Council or any other favourable powerful actors can implement the right to protect. How can interested international actors maximize the potential of the right to protect, the strongest and most compelling human protection regime in the current international security system? I call for a focus group to study the right to protect as a global security principle available to the UN Security Council in moments of crisis of legitimacy and paralysis. 